\title{
PRÓBA NAKREŚLENIA TEORII KONFERENCJI JAKO PEDAGOGICZNO-ARTYSTYCZNEGO WIDOWISKA KULTUROWEGO. NA PRZYKŁADZIE PRZEBIEGU KONFERENCJI „OD INSPIRACJI DO KREACJI. WYZWANIA EDUKACYJNE I ARTYSTYCZNE"
}

\begin{abstract}
Aвstract. Dembiński Mariusz, Próba nakreślenia teorii konferencji jako pedagogiczno-artystycznego widowiska kulturowego. Na przykładzie przebiegu konferencji „Od inspiracji do kreacji. Wyzwania edukacyjne i artystyczne" [An Attempt to Outline a Theory of the Conference as a Pedagogical and Artistic Cultural Spectacle. A Case Study of the Conference From Inspiration to Creation. Educational and Artistic Challenges]. Studia Edukacyjne nr 60, 2021, Poznań 2021, pp. 51-70. Adam Mickiewicz University Press. ISSN 1233-6688. DOI: 10.14746/ se.2021.60.3
\end{abstract}

The aim of the article is an attempt to outline the theory of the conference (scientific), taking into account its actual course, including the reported content, as the ontic basis of its real structure. At the heart of this concept is a myth whose stories form the basis for the emergence of cultural spectacles. In the case of a conference conceived as a spectacle, the founding form (myth) is skholé. The conference itself is shaped in two overlapping areas: firstly, it is subject to the process of ritualization, and secondly, it is subject to the coexistence of universal praxis. In view of the subject of the conference mentioned and analyzed here, this theory takes into account aesthetic and pedagogical interactions (principles), ignoring others (ethics, economy, politics, religion).

The conference theory should contribute to the understanding of its coherent thinking and operation structure; the importance of its impact on its participants, the legitimacy of its organization and study; the possibility of consciously shaping its course, in the cognitive - methodological context (I omit the otherwise important socio-cultural aspects).

Key words: conference theory, myth, ritualization, coexistence, cultural spectacle, skholé, pedagogy, aesthetics, Performer, Fokalizator

Istotą tej wypowiedzi jest próba nakreślenia pedagogiczno-artystycznej teorii konferencji jako widowiska kulturowego podległego mitowi, mając 
w tle na uwadze przebieg i poglądy prezentowane przez uczestników konferencji naukowej, zatytułowanej: „Od inspiracji do kreacji. Wyzwania edukacyjne i artystyczne" ${ }^{\prime \prime}$. Ponieważ próba ta w pierwszym rzędzie wymaga pewnych ustaleń ontologicznych i epistemologicznych, dotyczących sensu istnienia konferencji jako konferencji naukowej, toteż na nich skoncentruję swoje rozważania. Ich wykładnią uczynię mit sprowadzający konferencję do widowiska kulturowego, w którym zasadniczą rolę pełni proces rytualizacji, a w szczególności zasady wpisujące się w płaszczyznę koegzystencjalną całokształtu ludzkiej praxis, opracowanego przez Dietricha Bennera².

Powyższe zadanie wyłoniło się z krytycznego spojrzenie na - jak się zdaje - samounicestwiającą się formę konferencji w kontekście kreowania wiedzy naukowej, której uniwersytecka faktura od przeszło trzydziestu lat podlega regresowi, poddając swoją twórczą suwerenność upolitycznieniu, ekonomizacji i technologizacji ${ }^{3}$. Aby te procesy zawłaszczania i degrengolady w jakiś sposób na nowo przemyśleć, warto odnieść się do jej trwałych struktur, by odszukać mechanizmy tworzące i przekształcające sens jej istnienia. Zakładam, że wiedzę tę będzie można uzyskać poprzez próbę sięgnięcia do tak zwanych widowiskowych form kulturowych; regulatorów ludzkiego współistnienia, które są normalizowane przykładowo przez mityczne ${ }^{4}$, rytualne ${ }^{5}$, performatywne ${ }^{6}$ i narracyjne ${ }^{7}$ konstrukty wpisujące się w praktyki społeczno-kulturowe. Jedną z nich jest konferencja. Moim celem będzie zatem sformułowanie podstaw czy zarysu teorii konferencji.

Próbę realizacji powyższego zadania uzależnię od przyjęcia założeń teoretycznych, których wykładnią jest mit, regulujący społeczne współistnienie poprzez praktykę narracyjną - opowiadanie, które samo w sobie jest występem, spektaklem. Odgrywanie w swoim opowiadaniu ucieleśnia w formie kulturowej widowisko, którego spektakl w osnowie wiedzy naukowej prowadzi do wygenerowania praktyki, jaką jest konferencja. Praktyka ta, aby stała się powszechną formą świadomości uczonych, musi podlegać procesowi

${ }^{1}$ Konferencja odbyła się 21-22 listopada 2019 r. w Kaliszu, w siedzibie Wydziału Pedagogiczno-Artystycznego Uniwersytetu im. Adama Mickiewicza w Poznaniu.

${ }^{2}$ D. Benner, Pedagogika ogólna: Wprowadzenie do myślenia i działania pedagogicznego w ujęciu systemowym i historyczno-problemowym, przekł. D. Stępkowski, Warszawa 2015. 2017.

B. Stiegler, Wstrzasy. Głupota $i$ wiedza w XXI wieku, przekł. M. Krzykowski, Warszawa

${ }^{4}$ J-L. Nancy, Przerwany mit, [w:] J-L. Nancy, Rozdzielona wspólnota, przekł. M. Gusin, T. Załuski, Wrocław 2010.

${ }^{5}$ A. Szakolczai, In liminal tension towards giving birth: Eros, the educator, History of the Human Sciences, 2013.

${ }^{6}$ J. McKenzie, Performuj albo ... Od dyscypliny do performansu, przekł. T. Kubikowski, Kraków 2011.

${ }^{7}$ K. Rosner, Narracja jako pojęcie filozofii wspótczesnej, [w:] Narracja i tożsamość. Część I - Narracje w kulturze, red. W. Bolecki, R. Nycz, Warszawa 2004. 
rytualizacji, a w swojej aktualizacji, zależnej od jej tematu, oddziaływaniom koegzystencjalnym. W ten sposób konferencję zespala jej forma zapośredniczona w micie oraz sfera ludzkiej koegzystencji, które sprawiają, iż opowiadający, referujący kreują i wcielają, a tym samym usensowniają i konstytuują wspólnotę, potwierdzając swoją indywidualną przynależność do „bractwa” uczonych (ryc. 1).

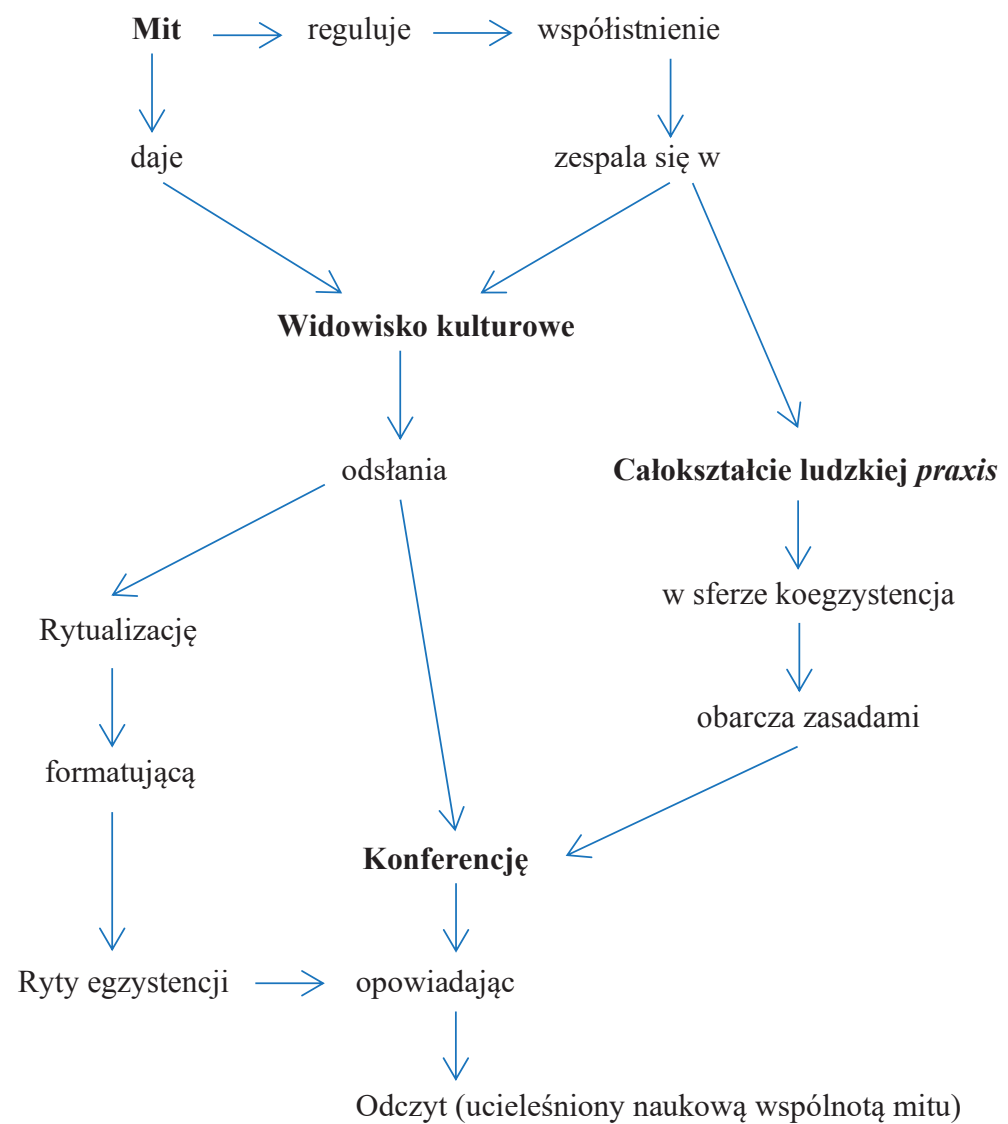

Ryc. 1. Teoria konferencji

(źródło: opracowanie własne)

Warto w tym miejscu zauważyć, że skoro tematyka konferencji uaktualnia jej sens i tworzy jej status, to niebagatelną rolę w "naszej” konferencji muszą odgrywać edukacja i sztuka. To głównie rządzące nimi zasady powinny konstytuować przestrzeń (scenografię i choreografię) dziania się tego 
naukowego „spektaklu”. Scena, do której przynależą uczeni aktorzy będzie rozszerzać się wraz z egzystencją myślicieli przebywających na korytarzach, salach wykładowych, w jadalniach, pokojach hotelowych i tak dalej. W tych ludzkich egzystencjach siłą sprawczą zawłaszczającą czas i przestrzeń, poniekąd tworzącą przestrzeń sacrum, będzie wzajemna zależność pedagogiki i sztuki (estetyki). Oznaczać to powinno, że w projekcie teorii konferencji jej formę należałoby podporządkować oddziaływaniom pedagogicznym i artystycznym, natomiast jej tematyce pozwolić wykorzystać kategorie inspiracji oraz kreacji, jak i tego, co się między nimi może znajdować, do przysposabiania inspiracji do tworzenia narzędzi w dwóch płaszczyznach: konferencji jako spektaklu i podmiotowej, kreującej naukowe narzędzia do wspólnotowego działania. W obu płaszczyznach inspiracja staje się nośnikiem performatywnych działań: wykonawczych i spełniających się w postawach uczonych, w postaci ucieleśniającej się $\mathrm{w}$ nich kreacji.

W ten sposób konferencja, jej tematyka i przebieg w sposób wykonawczy, praktyczny wzajemnie się dopełniają, wyposażając jej uczestników w określone umiejętności i przynaglając ich do refleksywności, czyli samozwrotnej wiedzy dotyczącej poczucia przynależności do wspólnoty naukowej. Znaczy to, i jest to podstawowa teza tej wypowiedzi, że konferencja w swojej zmitologizowanej formie, dopełnianej realizowanym w niej tematem, wyposaża jej uczestników w narzędzia poznania (głównie samopoznania), stanowiąc uposażenie do dalszego działania (pracy w sobie nad sobą - rozwoju).

Doszukując się w konferencji mitycznych podstaw, należy mieć na uwadze fakt - jak ma to zawsze miejsce w tego typu założeniach-przekonaniach - iż musi istnieć jej forma założycielska, a więc coś, co jest jej nośnikiem założycielskim i w kulturze przyjmuje się, że są to mity ${ }^{8}$.

Mit jest źródłowy i od początku odnosi się do mitycznego ustanawiania, a przez to odniesienie sam siebie ustanawia (świadomość, naród, opowieść). Wiemy, że jest to ustanawianie mityczne 9 .

Możemy przyjąć, iż początki konferencji powinny wywodzić się z antycznej Grecji, z tego, co wiąże się ze skholé10 jako formy wypoczynkowej po pracy, w których to spotkaniach opowiadano - „konferencjowano": słuchając i pytając. Skholé generuje w sobie systemy instrukcji dla społecznych form przekazu, wdrażania i przekształcania informacji w zinstytucjonalizowanych formułach ${ }^{11}$. 2016.

${ }^{8}$ M. Klik, Teorie mitu. Wspótczesne literaturoznawstwo francuskie (1969-2010), Warszawa

9 J-L. Nancy, Przerwany mit, s. 65.

${ }^{10}$ D. Kennedy, An Archetypal Phenomenology o Skholé, Educational Theory, 2017, 67, s. 273-290.

${ }^{11} \mathrm{H}$. Innis, Empire and communications, Toronto 2007. 
Pojęcie mitu ${ }^{12}$ (mythos) u swoich źródeł, w starożytnej Grecji, zespalało w sobie pojęcie logos i oznaczało w sumie opowiadanie. Kiedy w VI wieku p.n.e. dokonało się ich rozgraniczenie, mit zaczął oznaczać coś wymyślonego, fikcyjnego. Niemniej dla Paula Ricoeura ${ }^{13}$ mit jest opowieścią wskazującą na początek jakiejś rzeczy. Z kolei Northrop Frye ${ }^{14}$ doszukuje się w micie wzorca (paradygmatu) narracji, jako formy konstytuującej to, co na nim się opiera. Skoro „Frye twierdzi, że w pewnym sensie pisarze zapewniają przetrwanie opowieściom mitycznym w ciągle ewoluującej kulturze"15, to analogicznie można stwierdzić, że konferencja w swojej mitycznej opowieści zachowuje swoje istnienie w zmieniającej się kulturze. Uogólniając, można za Gilbertem Durandem powiedzieć, że mit to „(...) dynamiczny zespół symboli, archetypów i schematów, dynamiczny system, który pod wpływem schematu może układać się w opowiadanie"16. Przyjmijmy zatem, że tą dynamiczną formą systemu mitu - oczywiście w odniesieniu do konferencji - musi być konferencja, która na bazie kulturowych archetypów i zespalających się symboli $\mathrm{w}$ określone znaczenia podlega uschematyzowaniu, realizowanemu $\mathrm{w}$ dziejącej się rzeczywistości, której bycie i istnienie kreują oraz przekształcają przebieg konferencji w opowiadanie.

Zatem, każda naukowa konferencja, odwołując się do edukacyjno-naukowej macierzy, kreuje swoją opowieść, swoją narrację, przejawiając się w widowisku, w które wpisują się stematyzowane - niby sensem zawodowym, a jednak wynikające $\mathrm{z}$ głębokiego ukorzenienia (roots paradigmats - korzenne paradygmaty) - symbole i archetypy, oddziałując na zindywidualizowane przekonania uczestników konferencji, dotyczące poczucia własnej tożsamości i przynależności do określonej wspólnoty (naukowej). Poczucie własnej tożsamości, a przede wszystkim przynależność do wspólnoty prowadzą do edukacyjnego ukształcania (agoge - „doprowadzać") treści kultury w widowiska i sensu ludzkiej koegzystencji, warunkując ludzkie myślenie i działania. Zatem, mit przekształca i ukształca, prowadzi i doprowadza, zespalając wspólnotę w praktyki społeczno-kulturowe, wśród których z jednej strony będziemy mieć jej zinstytucjonalizowane formy wpisujące się $\mathrm{w}$ widowiska kulturowe, a z drugiej strony - system koegzystencjalnego współistnienia $\mathrm{w}$ ramach całokształtu ludzkiego praxis.

${ }^{12}$ M.-C. Huet-Brichard, Littérature et mytos et logos, Paris 2001, s. 14.

${ }^{13}$ P. Ricoeur, Mythes et mythologies dans la literature française, [w:] Encyclopædia Universalis, t. XI, Paris 1971, s. 795-797.

${ }^{14}$ N. Frye, Mit, fikcja, przemieszczenie, przekł. E. Muskat-Tabakowska, Pamiętnik Literacki, 1969, 2, s. 289-307.

${ }^{15}$ M. Klik, Teorie mitu, s. 89-90.

${ }^{16}$ Za tamże, s. 65. 
Konferencja również dlatego przynależy do mitu, ponieważ mit przekształca czas w przestrzeń ${ }^{17}$, w której - w przypadku edukacji (paideia) - skholé umożliwia debatę poza realiami życia potocznego, tworząc jego sacrum. „Z mitem ruch (écoulement) staje się figurą, nieustanne przechodzenie ustala się jako szczególne miejsce objawiania się i obcowania"18. W tych miejscach dopełnia się występ - widowisko kulturowe; performatywne spełnienie dopełniane procesem rytualizacji.

Toteż konferencyjne spotkania - jako znormalizowane praktyką społeczno-kulturową widowisko - w swoich przedstawieniach (performatywnych, wykonawczych wystąpieniach) osadzają uczonych w zmitologizowanej figurze archetypu, jakim jest skholé, dzięki któremu dopełnia się przynależność do wspólnoty, której pra-sens ukazują oraz uobecniają w swoich referatach uczeni i stąd stają się aktorami. Topos przynależności w swoim wystąpieniu, prezentacji czy odczycie stygmatyzuje jego uczestników - już samym aktem wystąpienia (performance) - procesowi rytualizacji widowiska. Erwin Goffman „występ” (widowisko) pojmuje jako: „(...) wszelką działalność danego uczestnika interakcji, $\mathrm{w}$ danej sytuacji służącą wpływaniu w jakiś sposób na któregokolwiek z innych jej uczestników"19. Ten wpływ dokonuje się w ramach dążenia do spełnienia, a Victor Turner traktuje jako „wykonanie”, które nie jest odtworzeniem - dodamy, że prostym odczytaniem tekstu - ale twórczym odtwarzaniem tworzonej na nowo rzeczywistości - rzeczywistości konferencyjnej, ujętej jako widowisko kulturowe. Dla Johna MacAloona

(...) widowiska kulturowe, to coś więcej niż rozrywka, więcej niż dydaktyczny lub perswazyjny przekaz, więcej niż katartyczne odreagowanie: to chwile, w których jako kultura bądź jako społeczeństwo podejmujemy refleksję nad samym sobą i definiujemy samych siebie, odgrywamy nasze wspólne mity i naszą historię, przedstawiamy alternatywne wersje samych siebie czy też zmieniamy się pod pewnymi względami, by pod innymi pozostawać tacy sami ${ }^{20}$.

Zatem, konferencja jako przedstawiająca się opowieść w swojej mitycznej osnowie składa się z prezentacji - naukowych "opowieści”, w których dopełniają się potrzeby jej uczestników w procesie rytualizacji do którego przystają, zdając się na moc sprawczą rytuałów, przylegających w swojej formie do mitów; do wspólnoty, w której jednostki doświadczają przemiany zachodzące $\mathrm{w}$ przestrzeniach ich egzystencji i koegzystencji. Peter McLaren stwierdza:

17 C. Lévi-Strauss, Z bliska i z daleka, przekł. L. Kołakowski, Warszawa 1993, s. 360.

${ }_{18}$ J-L. Nancy, Przerwany mit, s. 64.

${ }^{19}$ E. Goffman, Człowiek w teatrze życia codziennego, przekł. H. Datner-Śpiewak, P. Śpiewak, Warszawa 2000, s. 45.

${ }^{20}$ J.J. MacAloon, Wstęp: widowiska kulturowe, teoria kultury, [w:] Rytuat, dramat, święto, spektakl. Wstęp do teorii widowiska kulturowego, przekł. K. Przyłuska-Urbanowicz, red. J.J. MacAloon, Warszawa 2009, s. 12. 
Rytualizacja jest procesem, który zawiera inkarnację symboli, symbolicznych skupień (clostes), metafor, korzennych paradygmatów poprzez formatywny gest cielesny. Jako formy odtwarzanego znaczenia rytuały umożliwiają aktorom społeczne kształtowanie, negocjowanie i formowanie swojej fenomenologicznej egzystencji, jako społecznych, kulturalnych i moralnych istot ${ }^{21}$.

Mityczne ustanowienie konferencji jest jej mityzacją, co wskazuje na mityczność (fikcyjność) mitu (twórcy). Mityzacja odnosząc się do źródła i nierzeczywistości, które w ich odnawiających się ramach czynią każdy "występ” realną projekcją, jednocześnie dąży ku odnowie w nowych (uobecnianych odczytami) realiach społeczno-kulturowych, w których dopełnia się spełnienie poprzez proces rytualizacji. W tej perspektywie również konferencja „ $\mathrm{Od}$ inspiracji do kreacji. Wyzwania edukacyjne i artystyczne" wpisuje się w mit założycielski skholé, kreując na swój użytek własną opowieść doświadczanego współistnienia, przekształcając fikcyjność (wskazując nie tyle brak związku z czymś realnym, ile ideały zawłaszczające myślenie i działania uczoności) w prawdę. Prawdą tej konferencji jest jej koegzystencja oparta na pedagogice (edukacji) i sztuce (estetyka), wprowadzając zasady rządzące i regulujące współistnienia.

Zgodnie z poglądami D. Bennera ${ }^{22}$ na temat całokształtu ludzkiej praxis przyjmujemy, że człowiek jako istota niedoskonała jest obdarzony brakami, aby egzystować w społeczeństwie, a przy tym wyposażony w wolną wolę, dzięki czemu ma zdatność do twórczego działania (praxis) i tym samym przezwyciężania niedostatków natury, co w konsekwencji prowadzi sens bycia człowiekiem do nadawania sobie określenia i stawania się kimś niepowtarzalnym. Proces ten dopełnia się w środowisku społeczno-kulturowym, w relacjach międzypodmiotowych, w całokształcie ludzkiej praxis, a więc w tym, co uzależnia sens stawania się „człowiekiem”, zapośredniczonych w takich formach ludzkiego istnienia, jak: koegzystencjalna, egzystencjalna i inegzystencjalna - rycina 2.

Nas interesuje płaszczyzna koegzystencjalna, która - jak twierdzi D. Benner $^{23}$ - została wygenerowana z praktyki, z doświadczeń historycznych, które warunkują międzyludzkie współistnienie. Wyróżniono tutaj oddziałujące na siebie takie formy, jak: pedagogika, polityka, ekonomia, etyka, estetyka i religia $W$ płaszczyźnie tej jednostki poszukują własnych powołań do funkcjonowania w świecie, przekładających się na specyficzne działania i myślenie, które są między innymi regulowane przez zasady konstytutywne, to jest

${ }^{21}$ P. McLaren, Edukacja jako system kulturowy, [w:] Nieobecne dyskursy, cz. IV, red. Z. Kwieciński, Toruń 1994, s. 41.

${ }^{22}$ D. Benner, Pedagogika ogólna, s. 37 i n.

${ }^{23}$ Tamże, s. 27. 


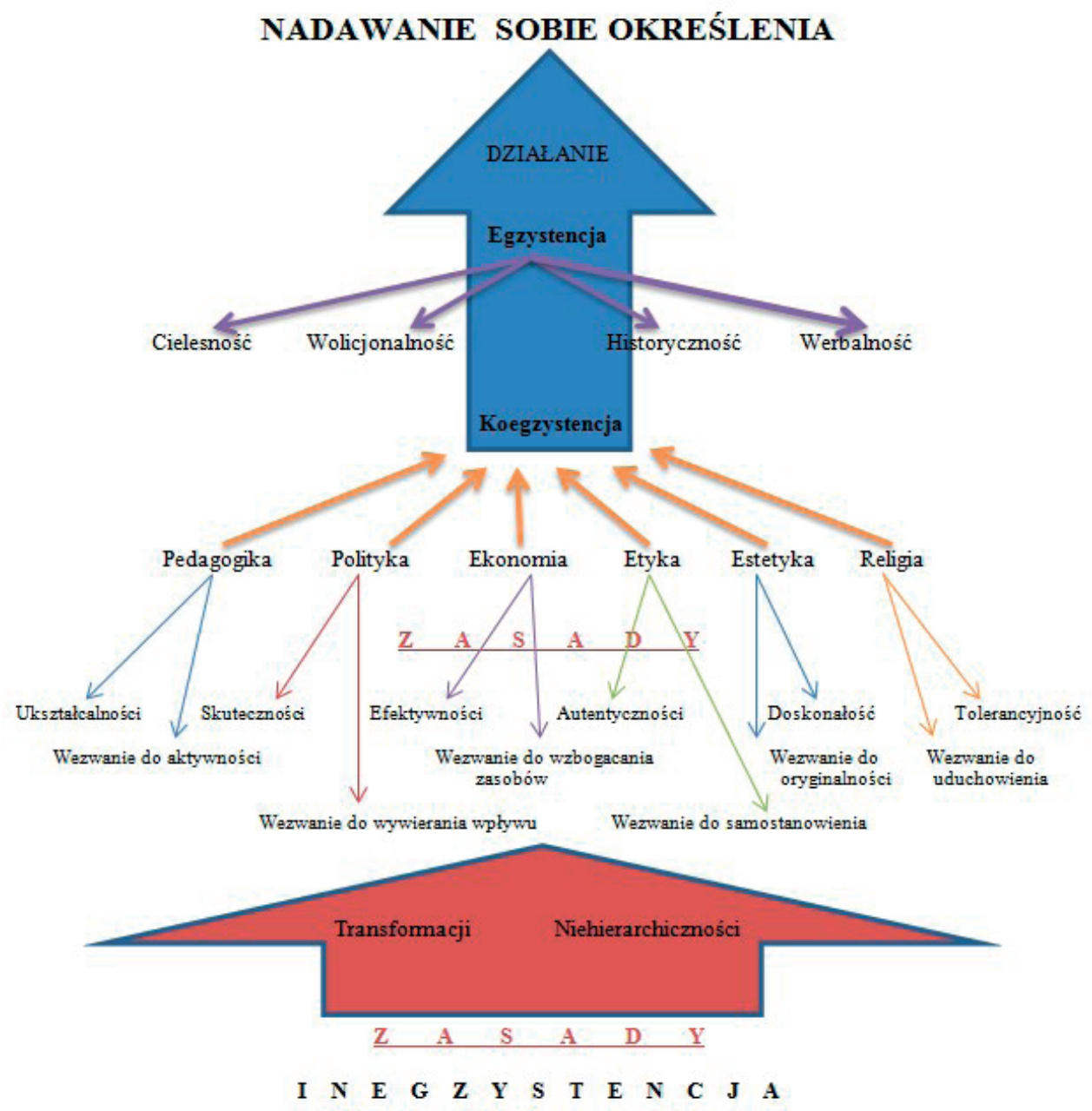

Ryc. 2. Struktura całokształtu ludzkiej praxis

(źródło: opracowanie własne)

konieczne, o charakterze historyczno-apriorycznym ${ }^{24}$. Te zasady to w przypadku pedagogiki ukształcalność i wezwanie do aktywności, a w przypadku estetyki (sztuki) - doskonałość i wezwanie do oryginalności (ryc. 3). Stanowią one reguły rządzące myśleniem i działaniem, i w przypadku pedagogiki, która edukując kształci, mamy ukształcalność oraz wezwanie do bycia aktywnym, natomiast w przypadku sztuki, która kształtuje - zasady doskonałości i wezwanie do bycia oryginalnym.

\footnotetext{
24 Tamże, s. 73.
} 


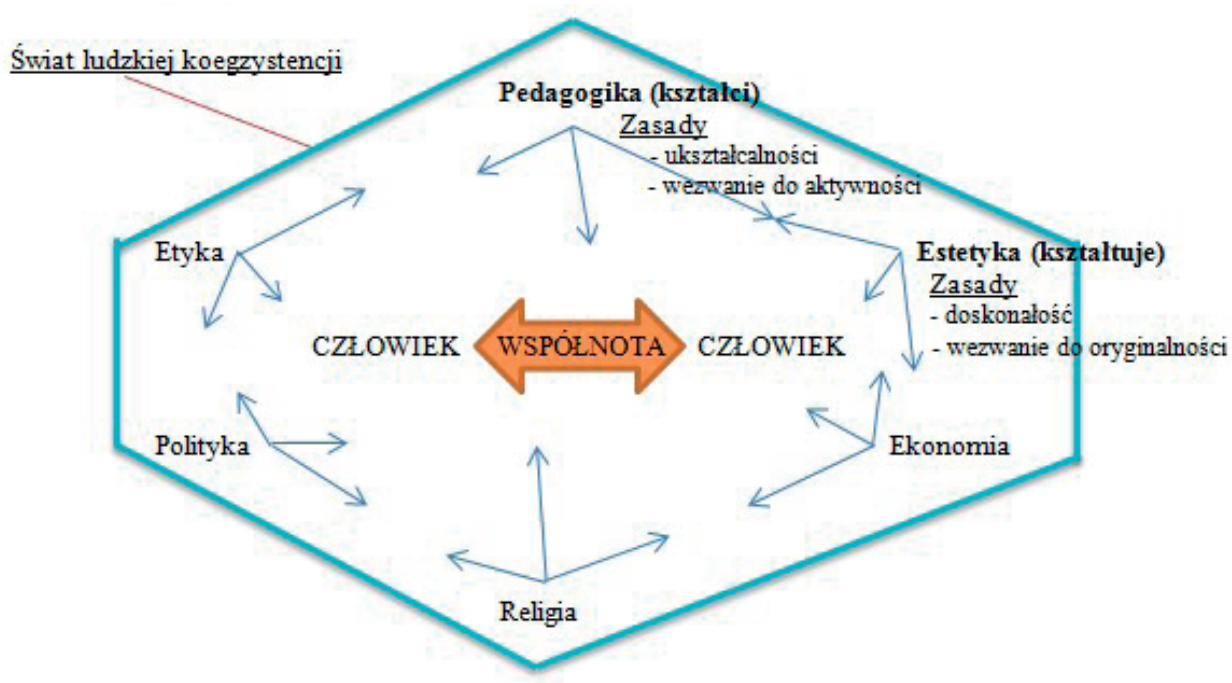

Ryc. 3. Płaszczyzny koegzystencjalne całokształtu ludzkiego praxis z wyróżnionymi zasadami pedagogiki i estetyki

(źródło: opracowanie własne)

Konferencja „Od inspiracji do kreacji. Wyzwania edukacyjne i artystyczne" w swojej tematyce zespalała - z uwagi na swój widowiskowy i koegzystencjalny „kształt” - edukację i sztukę, przez co zapośrednicza się w zrytualizowanej formie widowiska kulturowego i w problematyce całokształtu ludzkiego praxis. W ten sposób zdaje się być zrytualizowaną formą prezentacji myśli i działań, których uspójnienie dokonuje się w przestrzeni pedagogiki i estetyki, gdzie w ich spotkaniu dopełnia się kształcenie i kształtowanie wdrażanych w przebieg konferencji reguł (zasad) ukształcalności, doskonałości, wezwania do aktywności i oryginalności. Oznacza to, że osoby, które podporządkowały się tym zasadom stały się rzeczywistymi uczestnikami tej konferencji - uczestnikami jej tożsamej wspólnoty - wspólnoty wywiedzionej z mitu skholé.

Przyglądając się bliżej procesowi rytualizacji, podporządkowanej widowisku kulturowemu, do której należy dodać osnowę koegzystencjalną, nawiązujemy - w punkcie wyjścia - do rozpowszechnionych już od dziesiątków lat ustaleń dokonanych przez V. Turnera ${ }^{25}$ na temat czterech faz społecznej dramy. Składają się na nią takie fazy, jak: naruszenie reguł, kryzys, przywrócenie równowagi, w końcu reintegracja lub uznanie schizmy. Ten „schemat

${ }^{25} \mathrm{~V}$. Turner, Teatr $w$ codzienności, codzienność w teatrze, przekł. P. Skurowski, [w:] Antropologia widowisk. Zagadnienia i wybór tekstów, oprac. A. Chałupnik, W. Dudzik, M. Kanabrodzki, L. Kolankiewicz, wstęp L. Kolankiewicz, Warszawa 2010. 
na wszystkie okazje"26, jak stwierdził Clifford Geertz, należy nieco zradykalizować, uwzględniając płaszczyznę koegzystencjalną z wyróżnionymi dla naszych celów dwoma formacjami. W ten sposób na uczestnika konferencji, a więc na osobę referującą, będą dodatkowo oddziaływać zasady pedagogiki i estetyki (ryc. 4). W takim przypadku należałoby mówić o koegzystencjalnym dramacie społeczno-kulturowym.

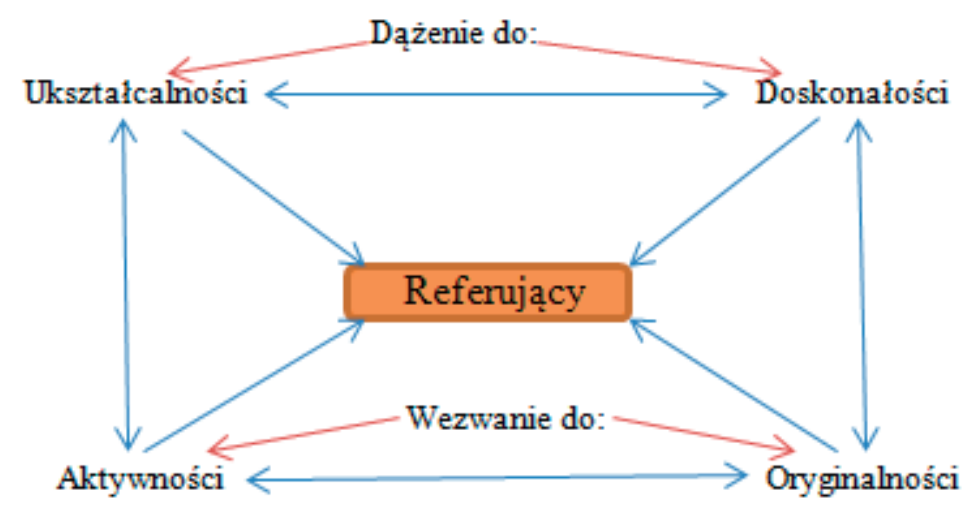

Ryc. 4. Rytualizacja konferencji

(źródło: opracowanie własne)

Jeżeli będziemy poszukiwać uzasadnień oraz odniesień wpisujących się w rytualizację konferencji poprzez fazy społecznej dramy, w odniesieniu do pierwszej jej fazy, która dotyczy naruszenia reguł, należy mieć na uwadze te zasady/reguły, których znaczenia doprowadziły do pojawienia się problemu na linii pedagogika - estetyka. Dążenia do i wezwania do (w kontekście pedagogiki i estetyki) przestały przystawać do siebie, co w rezultacie prowadzi do rytualnego chaosu ${ }^{27}$. Jego efektem jest kreowanie nowych doświadczeń i tym samym nabywanie nowych wiadomości poprzez uczenie $s i e ̨^{28}$. Dokonuje się to w trybie „przypuszczająco-spełniającym. V. Turner pisze: „Większość widowisk kulturowych należy do kulturowego trybu «przypuszczająco-spełniającego»" 29 . W trybie tym kładzie się nacisk nie na to co jest, ale na to co

${ }^{26}$ C. Geertz, O gatunkach zmąconych (nowe konfiguracje myśli społecznej), przekł. Z. Łapiński, Teksty Drugie, 1990, 2, s. 123.

${ }_{27}$ M. Czyżewski, S. Kowalski, A. Piotrowski, Rytualny chaos. Studium dyskursu publicznego, Kraków 1997.

${ }^{28}$ V. Turner, Liminalność i gatunki performatywne, [w:] Rytuat, dramat, święto, spektakl, s. 41.

29 Tamże, s. 42. 
może być, co przejawia się w pragnieniach, hipotezach, przypuszczeniach, dążeniach i tym podobnych. W ten sposób widowiska kulturowe, w tym i konferencja, wyłaniają się jako zwrotnie przekraczający się proces, w przekraczaniu którego wykracza się poza to co się uobecnia.

I jeżeli rytuał przejścia prowadzi do przemiany, która dokonuje się w przestrzeni liminalnej ${ }^{30}$, wygenerowanej przez A. van Gennepa ${ }^{31}$, to można doszukiwać się w tej przestrzeni oddziaływań o naturze „przypuszczająco-spełniającym”. Tutaj tylko wspomnimy, że A. van Gennep wyróżnił trzy fazy przejścia, a mianowicie: etap wyłączania (rites de separation), etap marginalny (rites de marge) oraz etap włączania (rites de agregation), które alternatywnie dookreślał przez takie pojęcia, jak: „preliminal”, "liminal” i „postliminal”32 (ryc. 5).

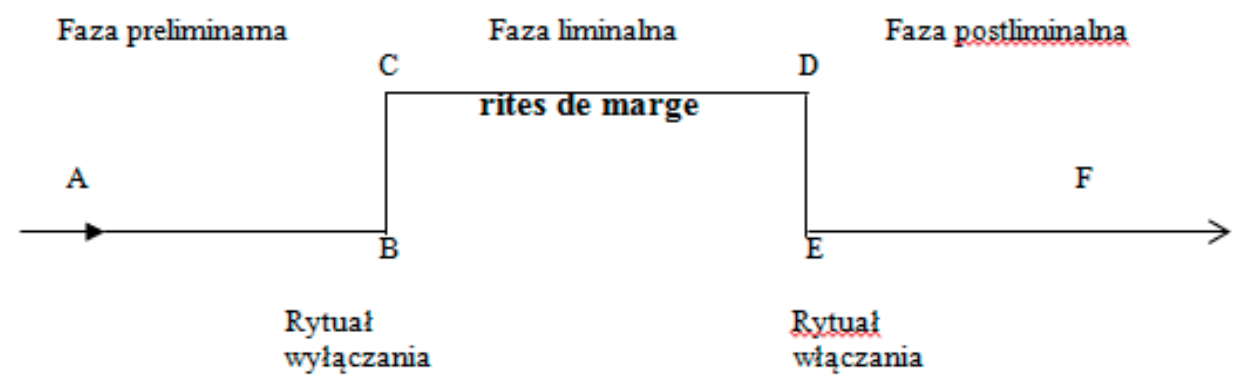

Ryc. 5. Struktura obrzędu przejścia

(źródło: M. Buchowski, Magia i rytuat, Warszawa 1993, s. 133)

To w fazie liminalnej należy doszukiwać się wszelkich ustaleń, decydujących o tym, co dopełnia się w trakcie naukowego spotkania, które przekształca się w konferencję, czyniąc jej/swoich prelegentów wykonawczymi performerami, którzy stają się jej odwzorowaniem, nośnikami - odwzorowanymi wzorcami (paradygmatyzującymi się paradygmatami). Tryb „przypuszczająco-spełniający" uspójnia to, co w fazie liminalnej jest kluczowe, czyli communitas i antystrukturę. Communitas ${ }^{33}$ uspójnia (mitologizuje) to, co nie jest ustrukturalizowane, co nie tylko wiąże się z naruszeniem reguł, ale z ich brakiem, a konkretnie - z brakiem ich ustabilizowania. I aby to co nieokreślone spełniło się w swoim dopełnionym przypuszczeniu, to uczestnicy konferencji muszą być zmarginalizowani, wykluczeni, aby mogła zadziałać sprawcza

\footnotetext{
${ }^{30}$ M. Buchowski, J.W. Burszta, O założeniach interpretacji antropologicznej, Warszawa 1992.

31 A. van Gennep, Rites of passage, London 1977.

${ }^{32}$ M. Buchowski, J.W. Burszta, O zatożeniach, s. 56.

${ }^{33}$ Tamże, s. 60.
} 
siła rytualizacji. Natomiast, antystruktura destabilizuje zinstytucjonalizowane formy odgrywanych ról w życiu społecznym, warunkując kreowanie dowolnych kreacji. I choć w czasie konferencji istnieją określone zasady pierwszeństwa, zachowania hierarchii, czy "czołobitności” (co również należy do widowiska), to przejawiają się $\mathrm{w}$ niej formy karnawalizacji ${ }^{34}$, które wcielając maski życia potocznego, prowadzą do zacieśniania więzi i kreowania wspólnoty w płaszczyźnie osobowej otwartości na drugiego.

Z uwagi na powyższe, pierwsza faza społecznej dramy w swojej koegzystencjalnej formie nie tyle będzie opierać się na naruszeniu reguł, ile na ich sposobach stabilizacji, unormowania, czy strukturalnego dopełnienia. Liminalność dopuszcza wszelkie warianty ustabilizowania się zasad konferencji, które ostatecznie będą dopełnione przez postawy jej uczestników, ale postawy, które będą wypływać z antystruktury - „mieszając” te oficjalne z tymi ukrytymi - przez karnawalizację zachowań. Konferencja ujawnia sposoby komunikowania na poziomie "meta”, co staje się czymś rzeczywistym i doświadczanym w bliskiej przyszłości dzięki trybowi „przypuszczająco-spełniającemu". Wyłaniająca się z doświadczanych przez siebie postaw i zachowań rama (frame) konferencji w jej procesualnym i zrytualizowanym ramowaniu pokazuje człowieka w jego całości: w prawdzie jego istnienia, a mówiąc dokładnie - w jego egzystencji.

Drugą fazą społecznej dramy jest kryzys, w obszarze którego zaczynają pojawiać się noszone w sobie urazy - „złe” doświadczenia z niektórymi uczestnikami konferencji, co uaktywnia wspomnienia, przeżyte emocje i określone nastawienie do konkretnych osób. Uspójnienie konferencji jest zagrożone, bowiem jej mityczne podłoże zostaje „ściśnięte” w swojej opowieści przez inne opowieści (negatywne lub pozytywne doświadczenia), przez co pojawiają się ugrupowania sprzymierzeńców i przeciwników ${ }^{35}$.

Druga faza konferencji będzie zatem regulować dążenie do wypracowania swoich reguł poprzez dychotomię postaw i działań, w tym i myśli - skonfliktowanych doświadczeniami, warunkowanymi ambicjami, poczuciem własnej wartości, jak i wdrażaną ideologią (dążeniem do uwiarygodnienia własnych przekonań).

Przezwyciężenie tej dychotomii, która może podlegać dalszemu podziałowi, a więc pluralizacji, staje się możliwe dzięki trzeciej fazie społecznej dramy i sile samego mitu. Uaktywnia on swoją opowieść, wpisując się w proces rytualizacji, którego liminalność i marginalizacja destabilizują struktury, a więc i uprzedzenia, kreując poprzez karnawalizację "brak” i możliwość bycia każdym i nikim. Destabilizacja jest warunkowana i nadzorowana przez

\footnotetext{
${ }^{34}$ W. Dudzik (red.), Karnawat. Studia historyczno-antropologiczne, Warszawa 2011.

${ }^{35}$ V. Turner, Teatr w codzienności, s. 62.
} 
temat konferencji, który staje się przewodnią opowieścią. Opowieść ta staje się władcą pojawiającej się dychotomii, decydując o dalszych jej losach.

W przypadku wskazanej tutaj konferencji, mit reguluje koegzystencję poprzez sam temat, który wpisuje się w jego strukturę poprzez uwypuklenie takich - swoich - elementów, jak: pedagogika i estetyka. Trzecia faza społecznej dramy to przywrócenie równowagi. W przypadku konferencji będzie zatem mowa o zrównoważeniu przeciwieństw, mitologicznie nadzorowanych przez zasady estetyki i pedagogiki, które są warunkowane trybem „przypuszczająco-spełniającym”. Toteż, wyłaniające się tutaj zasady: ukształcalności, doskonałości i wezwania do aktywności oraz do oryginalności stają się wyznacznikami uwspólniającymi formę tej konferencji.

Oznacza to, że pedagogika w swoim wykonawczym, performatywnym przymusie nadzoruje treści dziania się konferencji, a więc jej przebieg, jak i postawy jej uczestników poprzez ich ukształcanie i przynaglanie do aktywności, zaś od strony estetyki do przejawów doskonałości i oryginalności. Ta motoryka działań i nastawień uruchamia mechanizmy, które nadzorują ludzkie działanie i myślenie, co przekłada się na możliwość współpracy, zrozumienia i docenienia myśli przeciwnej strony w ramach jej dychotomii i jakieś jej zrównoważenie. Nie mamy tutaj do czynienia z przywróceniem równowagi - jak to mam miejsce w społecznej dramie - ale z eliminowaniem przeciwieństw, które nadzoruje mit - stematyzowana opowieść konferencji.

Czwartą fazą społecznej dramy jest reintegracja albo uznanie schizmy. Reintegracja uspójnia, natomiast schizma oznacza rozłam. W przypadku konferencji możemy mieć tylko do czynienia z reintegracją, z uspójnieniem, bo efektem konferencji ma być możliwość wpisania się we wspólnotę i nabycie tożsamości uczonego. Schizma zaś nie należy do konferencji; nie może do niej przynależeć, bowiem destabilizuje jej tryb „przypuszczająco-spełniający” wraz z jej mityczną podstawą. Zatem, osoby wpisujące się w schizmę sytuują się w jej ramach na jej marginalizujących siebie granicach, doświadczając wyalienowania - braku przynależności do uczonych.

Ostatecznie możemy stwierdzić, że konferencja jako widowisko kulturowe jest koegzystencjalnym dramatem społeczno-kulturowym, której przebieg w swojej procesualnej strukturze składa się z takich faz, jak: strukturalizacja reguł, dychotomia (pluralizmu) stanowisk, eliminowanie przeciwieństw i reintegracja.

Jak w takim razie należy pojmować konferencję naukową?

Przyjmujemy, że jest to struktura procesualna, składająca się z czterech następujących po sobie faz, nadzorowana przez rytualizację, wywiedziona z widowiska kulturowego oraz przez elementy koegzystencji ogólnoludzkiej praxis. Istotą konferencji są odczyty, wystawy, panele, dyskusje, spotkania w kuluarach i tym podobne. Jej przebieg podpada pod wcześniej zaplano- 
wany szczegółowy program, odzwierciedlający nastawienie organizatorów do tematu, zaproszonych gości, celów, które pragnie się osiągnąć i tym podobnych. Warto zauważyć, że każda konferencja w swojej sformalizowanej ramie organizacyjnej zawiera elementy trwałe i trwało-zmienne. Trwałe to te, które na stałe są wpisane w jej istnienie, jak na przykład rejestracja gości, powitanie uczestników, odczyty, dyskusje i tym podobne, bez których konferencja nie byłaby konferencją. Natomiast do elementów trwało-zmiennych należy zaliczyć miejsca z wyznaczonymi rolami do odegrania, w które wpisują się jej uczestnicy, jak na przykład pełnienie roli patrona honorowego, bycie moderatorem, osobą referującą, wystawiającą, dbającą o nagłośnienie i tak dalej. Oznacza to, że platformie (ramie) organizacyjnej konferencji towarzyszy rama jej instytucjonalizacji, która z uwagi na wyodrębniane cele do spełnienia wskazuje na funkcje i zadania do zrealizowania, przymuszające w płaszczyźnie kulturowej jednostki i grupy zwolenników czy przeciwników do określonych działań - występu.

Rama organizacyjna, jak i rama instytucjonalizująca pozwalają spojrzeć na konferencję jak na widowisko kulturowe w osnowie mitu, które w swoim wykonaniu (performance) jest tym, co wpisuje w siebie kategorię spełnienia - o której piszą na przykład "rytolodzy” - kładąc nacisk na jej funkcję (tryb) „przypuszczająco-spełniającą", gdzie należy dodatkowo uwzględnić płaszczyznę koegzystencjalną z funkcją kształtująco-kształcącą (estetyczno-pedagogiczną). Tego typu ukierunkowanie wskazuje na sztukę i edukację - na sztukę jako tę formę, która oddziałuje kształtująco i na edukację, która działa kształcąco. W sumie, powyższa idea przywołuje na myśl przykład rytuału przejścia Arnolda van Gennepa, społeczną dramę Victora Turnera, naśladowanie życia społecznego Gabriela Twardego i Rene Girarda, czy uczestniczenie i doświadczanie Luciena Levy'ego-Bruhla i Colina Tarnbulla. Od strony widowiska kulturowego wyłaniają się na przykład poglądy Richarda Schechnera, Jerzego Grotowskiego, Ervinga Goffmana, Petera Singera, Jona McKenziego, Eriki Fischer-Lichte i innych. Niewątpliwie, konferencja sprofilowana jest narracją. Prezentując się jako widowisko, opowiada historię, na którą - głównie - składają się wypowiedzi jej uczestników. Prowadzi do tego, że narracja konferencyjna w swoim cielesnym i językowym wykonaniu, przedstawianiu oraz prezentacji pozwala spojrzeć na jej uczestników, po pierwsze, jak na działających Performerów i tutaj mamy na uwadze referujących oraz dyskutujących, a po drugie - jak na wypowiadających się Fokalizatorów, czyli tych, którzy w koncepcji Gerarda Genetta ${ }^{36}$ wskazują na relację między narratorem a bohaterem. W przypadku konferencji naukowej chodziłoby o relację pomiędzy wypowiadającym się uczonym, dydaktykiem, artystą a tematem wypowiedzi. Performer, jak pisze Jerzy Grotowski:

\footnotetext{
${ }^{36}$ G. Genette, Discours du récit, [w:] G. Genette, Figures III, Paris 1972.
} 
jest człowiekiem czynu. A nie człowiekiem, który gra innego. Jest kapłanem, wojownikiem, jest tym, który działa; jest poza podziałami na gatunki sztuki. (...) Performer to stan istnienia. Człowiek poznania (...). Człowiek poznania rozporządza czynieniem, doing, a nie myślami albo teoriami. (...) Poznanie to sprawa czynienia ${ }^{37}$.

Natomiast Fokalizator jest człowiekiem odzwierciedlania, który gra swoją rolę w zinstytucjonalizowanej strukturze i w obszarze nauki rozporządza myślami (innych uczonych) oraz teoriami. Fokalizator w swoim referującym odzwierciedlaniu tematu konferencji jest zdeterminowany zasobami swojej wiedzy, prezentując własny punkt widzenia.

Oznaczałoby to, że w płaszczyźnie wydarzania się konferencji, z uwagi na pojęcie Performer, interesowałaby nas strona cielesna referującego, natomiast z uwagi na pojęcie Fokalizator należałoby zwrócić uwagę na wiedzę, w której zawierałyby się nie tylko przekazywane informacje, ale całokształt procesu inspiracji po kreację, na przykład wpisującego się w odczytywany tekst konferencyjny.

Dzięki narracji dopełnia się uspójnienie widowiska, a doszukując się w konferencji naukowej możliwości wyłaniania się dziejącej się (opowiadanej) historii, należy stwierdzić, że konferencja powinna być rozpatrywana od strony dramaturgicznej. I jeśli dodatkowo uzależnimy sens jej istnienia od dramaturgicznych wątków, które będą nadzorowane funkcją kształtująco-kształcącą w kontekście trybu „przypuszczająco-spełniającego”, to nadzorujący ją wymiar pedagogiczno-artystyczny (wraz z politycznym, ekonomicznym, religijnym i etycznym) może stać się źródłem przekształcenia jej struktury i tym samym nadać konferencji naukowej nową formułę.

Konferencje „Od inspiracji do kreacji. Wyzwania edukacyjne i artystyczne" w swojej narracji wypełniały wypowiedzi i wystawy. Prezentujący się - powiemy - Performerzy i Fokalizatorzy w trakcie swoich wystąpień podlegali rytuałowi przejścia, którego faza liminalna, nie tylko wpływała kształtująco na emocje i intelekt referującego, dookreślając jego świadomość na użytek jego poczucia własnej tożsamości i przynależności do jakieś wspólnoty, ale również na kształt i formę tej! konferencji. A tego to względu - w płaszczyźnie mentalnej - należy doszukiwać się - i tutaj kilkanaście przykładów - w wypowiedzi Jerzego Suchanka (Światło w edukacyjnej funkcji architektury) pewnego zaplecza pod scenografię konferencji, która wskazuje na edukację, stanowiącą twórczy nośnik dla uobecniania się estetycznych funkcji (w odniesieniu do piękna i brzydoty byłyby to: harmonia, symetria, proporcja) wynikających $\mathrm{z}$ architektonicznego zaplecza, w którym nośnikiem informacji jest światło. Z kolei rozważania Moniki Kostrzewy (Kreacja, moda, edukacja - wzajemne relacje obecne w procesie zmian kulturowo-estetycznych) można traktować jako uposażenie konferencji, ale nie tyle w formule jej dekoracji (mody jako wystroju

\footnotetext{
${ }^{37}$ J. Grotowski, Performer, [w:] J. Grotowski, Teksty zebrane, Warszawa 2012, s. 812-813.
} 
czy stroju), ile przejawu otwartości myślenia na zmiany w kontekście swobody własnych form wypowiedzi. Otwartość, na którą warto tutaj zwrócić uwagę, stanowi odniesienie do fazy liminalnej rytuału przejścia, w którym dopełnia się kreacja „bycia każdym i nikim” na wzór karnawalizacji - wyłomu $\mathrm{w}$ kulturze, jako poszukiwaniu nowych form egzystencji. Te poszukiwania znajdują swoje uzasadnienie w artykule Mariusza Dembińskiego (Tym samym bowiem jest wychowanie i malowanie). Mamy tutaj do czynienia z próbą wzajemnego utożsamienia pedagogiki i estetyki, jako bycie tym samym, co uspójnia sens konferencyjnego kształcenia z jej kształtowaniem (pedagogiki z estetyką). W podobnym duchu wypowiada się Małgorzata Ptak (Pragmatyzm idei i organizacji sztuki (w) edukacji), która nie tylko uściśla wzajemną zależność sztuki i edukacji, ale kładzie również nacisk na ich praktyczny wymiar, co podkreśla performatywny charakter konferencji. W rezultacie diachronię konferencyjnych wykonań przecina synchronicznie, z jednej strony, fenomen obrazu rzeczywistego, a z drugiej - fenomen obrazu poetyckiego. Małgorzata Piasecka w studium (Marzenie po skupieniu jako fenomen pomiędzy obrazem [peinture] a obrazem poetyckim [image]) sprowadza sens istnienia konferencji w wymiar marzeń, kładąc nacisk na wezwanie, które od strony sztuki przychyla się do bycia oryginalnym, a edukacji do przejawiania aktywności. W ten sposób płaszczyzna liminalna zwymiarowana communitas i antystrukturą zaczyna przybierać coraz bardziej określony kształt, zbliżając się do fazy postliminalnej. Kształt ten - już w trybie przypuszczająco-spełniającym - dopełnia tekst Mirosławy Ściupider-Młodkowskiej (Awangardowe formy relacji wirtualnych jako szansa dla wspótczesnej edukacji), który nacechowuje pole (topos) konferencji potrzebą ukształtowania $\mathrm{w}$ niej zmian, przełamywania schematów, jak i otwartości na to co inne, postępowe. $W$ tym kontekście mamy tutaj do czynienia z estetycznym dążeniem do ukształcania przebiegu konferencji w ramach estetycznej oryginalności. Konferencja uzyskuje zatem nie tylko swoją formę, ale i styl. Natalia Sheliahovich w swojej rozprawie (Aktualne interpretacje stylu jako kategorii naukowej w historii sztuki wspótczesnej) koncentruje się na pojęciu styl artystyczny, który staje się miarą rzeczywistej rytualizacji konferencji, jak i jej możliwości - od tej strony analizy. Styl bowiem jest formą urzeczywistniającej się wypowiedzi. Język z kolei jest tym, co generalizuje opowieść i przysposabia mit do współczesnych form współistnienia. Dorota Frątczak i Gracjana Herman (Istota i problemy kształcenia językowego na etapie edukacji wczesnoszkolnej) rytualizują formę konferencji treściami, które w swojej komunikacji uspójniają rytualizację w jej dążeniu do ukształcalności i doskonałości. W tym samym duchu można postrzegać odczyt Anny Łuczak (Kształcenie muzyczno-matematyczne a kompetencje kluczowe dziecka w zintegrowanej edukacji wczesnoszkolnej), która zestawiając matematykę ze sztuką integruje kształcenie z kształtowaniem, co wyposaża koegzystencjalne odziaływania 
na charakter konferencji, logiką myślenia i harmonią działania. Wpisujące się zatem w strukturę konferencji treści referatów opierają się gównie na kompetencjach, które są wyróżniane w słownych przekazach, stając się czymś, co wciela się w jej duchowość. Odczyt Gracjany Herman (Językowa kreatywność uczniów a ich możliwości komunikacyjne - wykorzystanie metody systemowej) jest tego kolejnym przykładem. Strukturalizujący się potencjał konferencji, który partycypuje w tym, co zostaje wypowiedziane, odczytane, wskazuje na jej poznawcze, jak i refleksyjne „usposobienie”. Opracowanie Katsiaryny_Dzichkouskaya (Heurystyka w nauczaniu literatury zagranicznej dla studentów języków uniwersyteckich: podstawa do projektowania modułu szkoleniowego) unaocznia ten potencjał, twórczo urzeczywistniany przez kształcenie, nauczanie i edukację. W ten sposób, proces kształtowania się konferencji staje się czymś realnym, prawdziwym, mentalnie rytualizując się jako widowisko kulturowe, które określiliśmy mianem koegzystencjalnej dramy społeczno-kulturowej. Tekst Roberta Pokleka (Transformacja systemowa jako wyzwanie dla ksztatcenia pedagogów) pozwala nam spojrzeć na konferencję jak na strukturę, która w swoim systemowo-sprawczym działaniu poddaje się słownym oddziaływaniom Fokalizatorów, formalnie wpływając na to, by stali się Performerami.

Konferencję, podobnie jak opowieść, należy traktować jako mentalną ideę zespalającą jej uczestników, kreując wspólnotę, która myślowo i działaniowo do niej przynależy, przez co staje się realnym artefaktem. Realność ta opiera się na konceptualizacji - pojęciu, do którego w swoich wykładach często odsyła Michel Foucault ${ }^{38}$. Konceptualizacja w swoim znaczeniu oznacza „upojęciowienie" tego, nad czym się dydaktycznie, naukowo i artystycznie pracuje, gdzie konceptualizacja, dodatkowo oznaczając „przetwarzanie” i „formowanie" na przykład pomysłów, doświadczeń, informacji, przemieszcza się na wyższy poziom istnienia, na którym funkcjonuje w sposób autoreferencyjny (do siebie samoodnoszący się), przetwarzając się w autokonceptualizację, autorefleksję, w której skrywają się oraz ujawniają fenomeny myślenia ${ }^{39} \mathrm{i}$ życia ${ }^{40}$, warunkujące - zgodnie z przyjętymi założeniami teoretycznymi - określone postrzeganie, doświadczanie i przeżywanie świata oraz rozumienie własnego istnienia czy doznawania własnej cielesności. Przejście z konceptualizacji do autokonceptualizacji pozwala widzieć na przykład proces inspiracji po kreację jako samoistny mechanizm, do którego przystaje człowiek, kiedy ma do wykonania twórcze zadania. Sens istnienia autokonceptualizacji przywołuje na przykład skojarzenia z koncepcją trzeciego królestwa, opracowanego

${ }^{38}$ M. Foucault, Trzeba bronić społeczeństwa. Wykłady w Collège de France, 1976, przekł. M. Kowalska, Warszawa 1998.

${ }^{39}$ G. Frege, Myśl - studium logiczne. Pisma semantyczne, przekł. B. Wolniewicz, Warszawa 1977, s. 127.

${ }^{40}$ M. Henry, O fenomenologii, przekł. M. Drwięga, Warszawa 2007. 
przez Gottloba Frege'a ${ }^{41}$, w którym myśli istoczą się w sposób niezawisły, dalej koncept trzech światów Karla Raimunda Poppera ${ }^{42}$, w którym wszelkie ludzkie wytwory istnieją niezależnie od człowieka i rządzą się swoimi prawami, a także poglądy Michela Henry' ego $^{43}$ na temat kategorii życia.

Autokonceptualizacja odsyłając nas do świata zjawisk kultury, wytycza również w sobie miejsce dla widowiska (performance), pod które - obok lekcji, karnawału, spektaklu, wystawy, niedzielnej mszy, turnusu rehabilitacyjnego dla seniorów i tym podobnych - podpada także konferencja naukowa.

Omówiona konferencja, która posłużyła nam do opracowania jej teorii, już zaistniała, przeszła do historii i z tej perspektywy można powiedzieć, że każdy jej uczestnik postliminalnie nosi w sobie wspólnie doświadczane treści jej dziania się, której opowieść ujęta jako koegzystencjalny dramat (widowisko) społeczno-kulturowe stanowi formę dla przeżywania jej w sobie, co przekłada się na możliwość jej opowiadania (w źródle mitu), a w konsekwencji - w przyszłości - na możliwość jej performatywnego i fokalizatorskiego wypowiedzenia, czyli twórczego odtwarzania.

Konferencja jako zjawisko kulturowe daje możliwość jej analizy od strony społeczno-kulturowej, stając się - w zasadzie - przedmiotem badań kulturoznawców. Niemniej, z uwagi na jej „żywą" formę strukturalizującą/modelującą myślenie i działanie referujących, nie powinna być traktowana jako miejsce w wymiarze sprawozdawczym. Jej topos jest żywy, modalny, emocjonalny, intelektualny, dyskursywny, transformatywno-performatywny. W ten sposób konferencja w swojej teoretycznej strukturze jawi się jako możliwa forma postrzegania - naukowego badania, koegzystencjalno-zrytualizowanego kreowania. Pozwala zatem ona - z uwagi na jej uspójnianie myślenia i działania - świadomie wpływać na jej uczestników, wdrażać określone formy postrzegania świata w postawy uczestników, odtwarzać, przekształcać i kreować paradygmaty. Dlatego, aby zrozumieć - również - jej kreacyjną rangę, warto studiować i badać jej przebieg, bowiem jest formą stanowiącą ważne źródło rozwoju myśli naukowej, jak i indywidualnego rozwoju uczonych w aspektach przynależności do określonych wspólnot (naukowych). Z tych to przyczyn konferencja powinna być badana przez przedstawicieli wszystkich dyscyplin wiedzy naukowej. W przypadku pedagogów jest na tyle znacząca, na ile edukacja jest pojmowana nie tylko jako narzędzie kształtowania, ale w szczególności jako narzędzie prowadzenia - oczywiście w jej immanentnej wykładni, nie podlegającej upolitycznieniu, ekonomii, czy technologii.

${ }^{41}$ G. Frege, Myśl - studium logiczne.

42 K.P. Popper, W poszukiwaniu lepszego świata, przekł. A. Malinowski, Warszawa 1997.

43 A. Gielarowski, R. Grzywacz (red.), Michel Henry - fenomenolog życia, Kraków 2010. 


\section{BIBLIOGRAFIA}

Benner D., Pedagogika ogólna: Wprowadzenie do myślenia i działania pedagogicznego w ujęciu systemowym i historyczno-problemowym, przekł. D. Stępkowski, Wydawnictwo Naukowe UKSW, Warszawa 2015.

Buchowski M., Burszta J.W., O założeniach interpretacji antropologicznej, Instytut Kultury, Warszawa 1992.

Czyżewski M., Kowalski S., Piotrowski A., Rytualny chaos. Studium dyskursu publicznego, Aureus, Kraków 1997.

Dudzik W. (red.), Karnawat. Studia historyczno-antropologiczne, Wydawnictwo Uniwersytetu Jagiellońskiego, Warszawa 2011.

Foucault M., Trzeba bronić społeczeństwa. Wykłady w Collège de France, 1976, przekł. M. Kowalska, Wydawnictwo KR, Warszawa 1998.

Frege G., Myśl - studium logiczne. Pisma semantyczne, przekł. B. Wolniewicz, Państwowe Wydawnictwo Naukowe, Warszawa 1977.

Frye N., Mit, fikcja, przemieszczenie, przekł. E, Muskat-Tabakowska, Pamiętnik Literacki, $1969,2$.

Geertz C., O gatunkach zmąconych (nowe konfiguracje myśli społecznej), przekł. Z. Łapiński, Teksty Drugie, 1990, 2.

Genette G., Discours du récit, [w:] G. Genette, Figures III, Éditions du Seuil, Paris 1972.

Gielarowski A., Grzywacz R. (red.), Michel Henry - fenomenolog życia, Wydawnictwo WAM, Kraków 2010.

Goffman E., Człowiek w teatrze życia codziennego, przekł. H. Datner-Śpiewak, P. Śpiewak, Wydawnictwo KR, Warszawa 2000.

Grotowski J., Performer, [w:] J. Grotowski, Teksty zebrane, Instytut im. J. Grotowskiego, Instytut Teatralny im. Z. Raszewskiego, Krytyka Polityczna, Warszawa 2012.

Henry M., O fenomenologii, przekł. M. Drwięga, IFiS PAN, Warszawa 2007.

Huet-Brichard M.-C., Littérature et mytos et logos, Hachette, Paris 2001.

Innis H., Empire and communications, Dundurn Press, Toronto 2007.

Kennedy D., An Archetypal Phenomenology o Skholé, Educational Theory, 2017, 67.

Klik M., Teorie mitu. Wspótczesne literaturoznawstwo francuskie (1969-2010), Wydawnictwa Uniwersytetu Warszawskiego, Warszawa 2016.

Lévi-Strauss C., Z bliska i z daleka, przekł. L. Kołakowski, Państwowy Instytut Wydawniczy, Warszawa 1993.

MacAloon J.J., Wstęp: widowiska kulturowe, teoria kultury, [w:] Rytuat, dramat, święto, spektakl. Wstęp do teorii widowiska kulturowego, przekł. K. Przyłuska-Urbanowicz, red. J.J. MacAloon, Wydawnictwa Uniwersytetu Warszawskiego, Warszawa 2009.

McKenzie J., Performuj albo ... Od dyscypliny do performansu, przekł. T. Kubikowski, Wydawnictwo Universitas, Kraków 2011.

McLaren P., Edukacja jako system kulturowy, [w:] Nieobecne dyskursy, cz. IV, red. Z. Kwieciński, Wydawnictwo Naukowe UMK, Torun 1994.

Nancy J-L., Przerwany mit, [w:] J-L. Nancy, Rozdzielona wspólnota, przekł. M. Gusin, T. Załuski, Wydawnictwo Naukowe Dolnośląskiej Szkoły Wyższej, Wrocław 2010.

Popper K.P., W poszukiwaniu lepszego świata, przekł. A. Malinowski, Wydawnictwo: Książka i Wiedza, Warszawa 1997.

Ricoeur P., Mythes et mythologies dans la literature française, [w:] Encyclopædia Universalis, t. XI, Encyclopædia Britannica, Paris 1971. 
Rosner K., Narracja jako pojęcie filozofii wspótczesnej, [w:] Narracja i tożsamość. Część I - Narracje w kulturze, red. W. Bolecki, R. Nycz, Instytut Badań Literackich PAN, Warszawa 2004.

Stiegler B., Wstrząsy. Głupota i wiedza w XXI wieku, przekł. M. Krzykowski, Wydawnictwo Naukowe PWN, Warszawa 2017.

Szakolczai A., In liminal tension towards giving birth: Eros, the educator, History of the Human Sciences, 2013.

Turner V., Liminalność i gatunki performatywne, [w:] Rytuat, dramat, święto, spektakl. Wstęp do teorii widowiska kulturowego, przekł. K. Przyłuska-Urbanowicz, red. J.J. MacAloon, Wydawnictwa Uniwersytetu Warszawskiego, Warszawa 2009.

Turner V., Teatr w codzienności, codzienność w teatrze, przekł. P. Skurowski [w:] Antropologia widowisk. Zagadnienia i wybór tekstów, oprac. A. Chałupnik, W. Dudzik, M. Kanabrodzki, L. Kolankiewicz, wstęp L. Kolankiewicz, Wydawnictwa Uniwersytetu Warszawskiego, Warszawa 2010.

van Gennep A., Rites of passage, Routledge and Kegan Paul, London 1977. 